\title{
CONCEPTS OF HRIDAY (AYURVED) IN THE SENSE OF HEART AND BRAIN
}

Vaikos Chandrashekhar Dattatraya*

Associate Professor, Dept of Rachana Sharir, Government Ayurvedic College, Nanded, India

Received on: 13/10/12 Revised on: 30/11/12 Accepted on: 18/12/12

\author{
*Corresponding author \\ E-mail: vaikosc@gmail.com \\ DOI: $10.7897 / 2277-4343.04133$ \\ Published by Moksha Publishing House. Website www.mokshaph.com \\ All rights reserved.
}

\section{ABSTRACT}

The concept of Hriday is found in almost all text of Ayurved which is considered or taken as 'Heart' by Ayurvedic specialties. It is considered that the concept of brain is not described in Ayurved. As in modern science and hence it is thought that brain is the only concept of modern science and Ayurveda is far away from this concept which is totally wrong. Most of the scholars and expert of Ayurveda consider 'Hriday' as Heart only. Recent research reveals that there are two brains, one in cranial cavity and other is situated in Heart itself. An attempt is made to study Hriday which is described under "Arthe Dash Mahamuliy Adhyaya", and Trimarmiya Adhyaya of Carak Samita and Hriday in Garbh-vyakaran Shariropkramniya Adhyaya (Chapters on embryology) of Sushrut Sharir Sthan (Anatomy by Sushrut) and whether it has same meaning indicating similarity with brain and heart or different meaning and its broader aspect with respect to brain in line with modern research.

Keywords: Hriday, heart, brain, Atma (soul), chetana (consciousness), buddhhi/intellect, sadhakpitta

\section{INTRODUCTION}

In Ayurveda, we find multiple meanings attributed to a single term. A few examples are given below.

- Hridaya means both (a) the heart and (b) the brain. (c) the Aatma (soul)

- Nidaana means (a) cause of disease and (b) Panchanidana, the five - fold methods to know a disease viz., nidana (cause), Poorvarupa, roopa, upasaya and samprapati.

- Rasa means (a) the six rasas of the food, (b) the aahara rasa (the final product of digestion of food), (c) the rasadhaatu (the first tissue formed from the ahararasa i.e. food rasa), (d) the metal mercury. The first three terms viz. six Rasas and rasa and rasa dhatu are all quite different materials but all the three are indicated by the term "rasa" only and that too while discussing the single process of digestion.

There are many such examples where a single term has been used in Ayurveda to indicate different materials.

In Indian literature both Ayurvedic and Philosophical Hriday indicates two anatomical structures 1) the brain and 2) the heart.

It is not correct to infer that in Ayurvedic literature Hriday indicates the heart in all cases. In many places, it indicates nothing but brain. There are many places where Hriday has been used in the sense of brain in Ayurveda, for e.g. Arthedash Mahamuliya Aadhya of Sutrasthan in Carak Samhita.

\section{Aims and objects}

The aim of study was to clarify the meaning of Hriday which is used in different locations so that it may help the Ayurvedic Physicians to take proper care of patient. It is necessary to throw some light on text to visualize the concept of Hriday as brain and heart.

\section{MATERIALS AND METHOD}

As this is literary or conceptual type of research, Texts books of Carak, Sushrut, Vagbht, Sharangdhar Samhita helped to draw proper conclusion and hence these books were used. Research article available on internet was used to support the Ayurvedic concept of Hriday which is quite similar to ancient text.

\section{Review of literature}

There were about 11 passages quoted in Ayurvedic literature which proves Hriday as Heart and Brain

Though the term Hriday is mentioned in Carak, Sushrut Samhita but they have not mentioned the physiology of Hriday especially how mind, intellect, senses of perception works and perform their function though they are situated in Hriday. As for instance the verse "Arthedashmahamooliya Adhya" quote -

The Hriday is the abode of six main organs (head, trunks and four limbs), science/knowledge, five senses and their five objects, soul invested with attributes, the mind and its subjects/objects of thoughts, the Oja Dhatu, consciousness or chaitanya. If the Hriday is disordered/injured/derranged then unconsciousness is lost, if destroyed the limbs of the body are annihilated and thereby death occurs. The Jivatma (soul of living) itself is aware of cognizable things by perceptions and is known by name Holder i.e. "Dharii". This Holder or Dharii is placed in Hriday. The union of body, Indriyas (organs of senses and organ of work like defecation, micturation, locomotion, give and take e.g. hand) mind and soul is called the Holder (or Dharii) ${ }^{1}$. In this passage Atma (soul) with attributes has been mentioned. The attributes of Atma is "desire, malice, happiness, sorrow, instinct, consciousness, apprehension, intellect, memory and vanity. $^{2}$

Some passages where the term Hriday is used under above mentioned items are quoted below.

- The Hriday is special seat of consciousness. The channels (carrying the vital principals of the body) are 
attached to it and it is under the effects of Tamas sleep. ${ }^{3}$

- The fetus is endowed with consciousness owing to the formation of Hriday as this endowed with consciousness. It is the seat of knowledge, intellect and mind. ${ }^{4}$

- Doshas becoming excited of the persons whose minds are assailed by rajas (passion), tamas (darkness) and the rest seize the Hriday (which is the foremost seat of the inner-self \& senses and locate them there). While located there and stirred by the impulses of lust, wrath, fear, cupidity, joy, grief and anxiety, they overwhelm the Hridaya. The result of this is that the persons becomes subject to a fit of epilepsy (Apasmar). It is temporary introgression in to darkness, accompanied by hideous contentious owing to the drawings of memory, understanding and mind.5. While describing Epilepsy (Apasmar), Carak and Madhavnidan mentioned that Apasmar (Epilepsy) is the disorder of Hriday. Because of weak mind, the Doshas gets vitiated and they vitiate Hriday (where Intelligence abode) and overwhelms channels (that convey sensation to the mind) that stupefies the mind quickly. Hriday being seat of mind is aggravated by wine. In addition Hriday is said to be the seat of channels that regulate the passage of Ras (nutritive fluid formed after digestion of food) and other Dhatus (cells \& tissue), mind, the understanding, the senses, the soul and ojas which is foremost of the Dhatus. Vayu (Air) under the influence of anxiety, grief etc. gets vitiated \& occupies the Hridaya and destroys memory \& produces epilepsy. ${ }^{5}$

- Wine on entering the Hriday by its ten qualities, destroys the ten qualities of the Ojas and brings the minds in to an abnormal condition called as Unmad (insanity/mania/psychosis) ${ }^{6}$

- Carak in Trimarmimeeya Adhyaay describes the etiopathology of Apatantrak (Hysteria) as when Vayu is aggravated by appropriate causes, it migrates upwards from its own site and reaches the Hriday. It affects Hriday and produces pain in Hriday, head and temples and when aggravated Vayu leaves the Hriday, patients gets relief and when affected again patient becomes unconscious. When kapha occupies the Hriday it covers the intelligence and induces sleep ${ }^{7}$.

- In Hriday there are seated the ten Dhamanis, praana, udan vayus, mind, intelligence, consciousness and five mahabhootas. Just as the rays of the sun are being supported by sun, similarly the senses of perception and the channels of the senses and life are also being supported by the head. ${ }^{8}$

- Five mahabhootas (basic constituent element from which the universe is formed) $)^{9}$ in above passages means five objects of the five senses of perception. Thus, 1) kshiti (earth) bhoota i.e. carrier of smell. 2) aapa (water) bhoota i.e. carrier of taste 3) teja (digestive fire/capacity) bhoota i.e. carrier of form. 4) Vayu (air) bhoota i.e. carrier of touch 5) aakash (space) bhoota carrier of sound. Each of these has separate Dhamani (nerve) to carry the above mentioned ten sensible objects. Here ten does not mean ten numbers but ten kinds of sensible objects.

- Any pathological condition or accidental injury to Pranvaha Srotas (microscopic or macroscopic passage/carriers of oxygen) Hriday and Rasvahidhamanya (channels or vessels conducting nutritive fluid formed after digestion of food) may manifest in anger, bending of body, vertigo, tremors, convulsions and death. ${ }^{10}$

- Sadhak pitta is located in Hriday ${ }^{11,12}$. Sadhak pitta eliminates the covering of cough and tam from Hriday and thus makes it more susceptible for perceptions, knowledge, intelligence and Ahankar i.e. pride/proud.

- References from Yogvashishtha $(32,33,34)^{13}$ clearly indicates that there are two Hriday in body.

- Sharangardhar states in part-1, Hriday is situated in thorax between breasts. Further he quotes human body is nourished because of pure blood (shudhdha rakta) circulated by Hriday with the help of Vyan vayu. ${ }^{14}$ In Marmasharir of Sushrut Sharirasthan, Sushrut says that in between the two breast and in thorax at the entrance of the orifice of stomach is the vital spot called Hriday which is the seat of three properties of Mind, satva, rajas and tama. ${ }^{15}$

- Hriday is origin or seat of Pran vaha Srotas and Ras Vaha Stotas 16

\section{DISCUSSION}

The above mentioned 28 passages indicate that soul, chetana, mind, cheta, intellect, memory, knowledge, consciousness etc are seated in Hriday. Soul, chetana and consciousness are same thing, while mind and cheta are the same thing again. Again as the Hriday is the seat of intellect so senses are the seat of intellect. Since the chief seat of soul and mind (as the mind is the leader of ten Indriyas) is Hriday. If we can identify the seat of mind, sense organ (indriyas) and the life carrying srotas, then Hriday will be identified easily.

Carak says that parts of body in which the life breaths are said to inhere, to which all senses are said to belong and which is said to be the most important of all the limbs of the body, is called by the name of head - Siras. ${ }^{17}$

It is quite clear that the seat of mind, sense organs and life as well as soul, intelligent, etc is in head especially in between skull and Palates i.e. in brain. Besides the determination of seat of mind, the location of Hriday may be settled by the identification of the seat of the objects of soul and mind.

\section{The identification of the seat of soul and mind}

The objects of Soul - Caraka says 'the desire, aversion, happiness, sorrow, efforts, consciousness, knowledge, memory, intellect and ego are the objects of soul. ${ }^{18}$

Some are in the opinion that sire, aversion, happiness, sorrow and effort are the qualities of soul.

The objects of mind as caraka says thinking, deciding, discussion, grasping and determination and anything perceived by the mind like happiness, sorrow, desire, aversion and other thinkable things are the objects of mind. ${ }^{2}$

A study of the objects of soul and mind shows that all objects e.g. desire, aversion, happiness, sorrow, care, 
consciousness, apprehension, intellect, pride, thought, judgment, argument, contemplation and determination are received by soul and mind seated in Hriday. Now question is that whether these objects are received by brain or heart. According to ancient and modern science these are the subjects of the brain, none of them are of heart. Thus it is clear that the seat of soul, mind, intellect is not located in heart but in brain.

The above mentioned verses which deal with apoplexy, insanity indicate that the nervous system is being vitiated and produces diseases like apoplexy, insanity which are the diseases of brain and not of heart.

It has been mentioned that unconsciousness, apoplexy, insanity, aptantrak, paralysis, convulsions are the diseases of brain not of heart.

Shape of Hriday and its similarity with Heart and Brain

The shape of Hriday is like a lotus whose apex or mouth is directed downwards. This Hriday contracts during sleep and dilates when awake. ${ }^{19}$

The heart with aorta and brain with spinal cord appears like lotus (with long slender stem) as described by Sushrut in above passage. Both organs have downwards direction and spinal cord and descending aorta resembles the stem or stalk of lotus. This Hriday performs and regulate the functions of nervous system and circulatory system. In cerebro-vascular accident both organs are affected.

"Recent study reveals that Heart and brain interact in a dynamic relationship that regulates many aspects of cognition and emotional experience. There is more information move from the heart to the brain than the other way around, and this information influences region's in the brain that affect decision making, creativity and especially emotions.

The general idea is that the body is a downward system, but $85-90 \%$ of all neural fibers carry information from the body to the brain, and a major part of this information comes from the heart via the nervous vagus ${ }^{20}$. The DNA in brain cells and in heart cells are completely identical. Both types of cell come originally form stem cells, and therefore contain the same genetic material. The only difference between brain and heart cells is how they use that DNA code ${ }^{21}$. Moreover the brain and heart have excitable cells. The excitable cells are those that can be stimulated to create a tiny electric current. Muscle fibers and nerve cells (neurons) are excitable. ${ }^{22}$

The above reference suggests that heart and brain are functionally related with each other.

The heart has its own intrinsic nervous system that operates and processes information independently of the brain or nervous system. It has long been thought that conscious awareness originates in the brain alone. Recent scientific studies suggest that consciousness emerges from the brain and body acting together. As it has been shown that a growing body of evidence now suggests that the heart plays a particularly significant role in this process. ${ }^{23}$ Neuroscientists have found that the heart has its own independent nervous system - a complex system referred to as "the brain in the heart." There are at least forty thousand neurons (nerve cells) in the heart - as many as are found in various sub cortical centers of the brain. The heart communicates with the brain and the rest of the body in three ways documented by solid scientific evidence: neurologically (through transmissions of nerve impulses), biochemically (through hormones and neurotransmitters), and biophysically (through pressure waves). In addition, growing scientific evidence suggests that the heart may communicate with the brain and body in a fourth way - energetically (through electromagnetic field interactions). Through these biological communication systems, the heart has a significant influence on the function of our brains and all our physical systems. ${ }^{24}$ Far more than a simple pump, as was once believed, the heart is now recognized by scientists as a highly complex system with its own functional "brain." Research (in the new discipline of neurocardiology) shows that heart is a sensory organ and a sophisticated center for receiving and processing information. The nervous system within the heart (or "heart brain") enables it to learn, remember, and make functional decisions independent of the brain's cerebral cortex. Moreover, numerous experiments have demonstrated that the signals by heart continuously sends to the brain influence the function of higher brain centers involved in perception, cognition, and emotional processing. ${ }^{25}$

Now it is clear from above mentioned references that heart and brain has functional similarity and Ayurvedic science has described functions of Hriday which is quite close to above research paper. Ayurveda described brain and heart under one roof i.e. Hriday which indicates both organ.

\section{RESULT}

The above mentioned verses from Ayurvedic texts which deals with insanity, apoplexy, aptantrak (hysteria) pakshavadha, (haemiparesis) akshep (convulsions) indicates that these are the diseases of nervous system especially brain and not the muscular organ heart.

Hriday described as the seat of knowledge, mind, thoughts, oja, intellect, memory, life, five sense organ and their objects clearly indicates the function of brain and not that of heart.

Yogvashishtha mentions that there are two Hriday one is thoracic and other is in head ${ }^{25,13}$.

Sushrut while describing Garbhavyakaran sharir (embryology) has mentioned that pleeha and phuphus (spleen and lung) are placed below the left side of Hriday where as yakrut (liver) and klom (gall bladder) are situated below the right side of Hriday ${ }^{19}$. This verse indicates muscular heart which is found in thoracic region. In addition to this he has mentioned in Marmasharir that Hriday is located between the breasts in thorax ${ }^{15}$ and the same type of references is quoted by Sharangardhar. This clearly shows thoracic Hriday i. e. Heart.

Now it is proved that the thoracic Heart now has its own functional brain. Heart is not only single pump but heart is sensory organ and sophisticated center for receiving and processing information. Thus in addition to circulation of blood heart works as brain also. 


\section{CONCLUSION}

The 11 passages quoted above from Ayurvedic literature and from recent research and study of heart and brain obtained by Internet definitely prove that Hriday is used to indicate Brain and heart as combined and never alone as generally believed.

\section{REFERENCES}

1. Carak Samhita (Sutrsthan,-30/2, 4, 6, 7) part-1, Kashinath Shastri Chaukhambha Sanskrit Sansthan.Varaanasi, Edition-8. p 442-443

2. Carak Samhita (Sutrsthan 17/12,) part-1,Kashinath Shastri, Chaukhambha Sanskrit Sansthan.Varaanasi, Edition-8, p 231

3. Sushrut Sahmita Sharir Sthan 4-33,34 B.G.Ghanekar,Published By Mauharchand Lachhmandas, New Delhi 1995. P 126

4. Sushrut Sahmita Sharir Sthan B.G.Ghanekar,Published By Mauharchand Lachhmandas, New Delhi 1995 (S.sh. 3-21)

5. Carak Samhita (Nidansthan- 8-4, p 536 and Chikistasthan 10/4,5 p 328) part-2, Kashinath Shastri Chaukhambha Sanskrit Sansthan.Varaanasi, Reprint-1998

6. Carak Samhita (Chikistasthan $9 / 5$ p 305 and 24/35, 36 p 672) part-2, Kashinath Shastri Chaukhambha Sanskrit Sansthan.Varaanasi, Reprint-1998

7. Carak Samhita (Sidhdhisthan-Trimarmiya Adhyaya-9/12-15 p 1055\& p1057/21,22, 23) part-2, Kashinath Shastri Chaukhambha Sanskrit Sansthan.Varaanasi, Reprint-1998

8. Carak Samhita (Sidhdhisthan-Trimarmiya Adhyaya-9/4 p1051) part-2, Kashinath Shastri Chaukhambha Sanskrit Sansthan. Varaanasi, Reprint-1998

9. Guidelines on basic training and safety in Panchkarm, Page 73-76, Published by Dept of AYUSH, Ministry of health and family welfare New Delhi 2008.

10. Sushrut Sahmita Sharir Sthan B.G.Ghanekar,Published By Mauharchand Lachhmandas, New Delhi 1995

11. Sushrut Samhita Sutrasthan 21/10 p 89 Part 1 by Ambikadatta Sahastri Chaukhamba Sanskrit Sansthan.Varaanasi Edition Reprint 2007
12. Sarth Vagbhat SutraSthan $12 / 13$, p 55, by V. H. Garde, Anmol Prakashan Pune Edition 1, 1999

13. Text book - on Yogvigyan by Yogvashishth $(32,33,34)$

14. Sharangdhar. Samhita. Purva-Khand $-1 / 5-76,78$, p 100 (Shn.San.Purva Khand Part-1/76,78)

15. Sushrut Sahmita Sharir Sthan 6/34, p 239, B.G. Ghanekar, Published By Mauharchand Lachhmandas, New Delhi 1995

16. Sushrut Sahmita Sharir Sthan 9/12, p 239 \& 9/15, p 241, B.G. Ghanekar,Published By Mauharchand Lachhmandas, New Delhi 1995

17. Carak Samhita (Sutrsthan 17/12, p 231) part-1,Kashinath Shastri, Chaukhambha Sanskrit Sansthan. Varaanasi, Edition-8

18. Carak Samhita Sharir Sthan 1/72, p 705) part-1,Kashinath Shastri, Chaukhambha Sanskrit Sansthan. Varaanasi, Edition-4/1994

19. Sushrut Sahmita Sharir Sthan 4/31, p 117, B.G.Ghanekar,Published By Mauharchand Lachhmandas, New Delhi 1995

20. The relationship between heart-brain dynamics, positive emotions,coherence, optimal health and cognitive function, Dirirr. Rollin McCraty PhD, (www.coherenceinhealth.nl) Date- 10/8/2012

21. Comparison between DNA of brain cell and heart cell http://wiki.answers.com/Q/Compare_the_DNA_in_your_brain_cells to the DNA in your he art cells

22. Excitable cells of heart and brain (users.ren.com//Biology Pages/E/ExcitableCells.html ) Date-15/9/2012

23. The Heart, Mind and Spirit, Professor Mohamed Omar Salem, http://www.rcpsych.ac.uk/pdf/Heart,\%20Mind\%20and\%20Spirit\%2 $0 \% 20$ Mohamed\%20Salem.pd f - Date-10-10-2012

24. The heart has its own brain and consciousness, mindful muscle, (file:///C:/Documents\%20and\%20Settings/Administrator/Desktop/a yur\%20articles/The\%20Heart\%20Has\%20Its\%20Own\%20"Brain" $\% 20$ and $\% 20$ Consciousness $\% 20-\% 20$ Stro ) date-20/10/2012

25. Text book - on Yogvigyan by Yogvashishtha - (35).

\section{Cite this article as:}

Vaikos Chandrashekhar Dattatraya. Concepts of Hriday (Ayurved) in the sense of heart and brain. Int. J. Res. Ayur. Pharm. 2013; 4(1):92-95 